Virginia Commonwealth University

VCU Scholars Compass

Obstetrics and Gynecology Publications

Dept. of Obstetrics and Gynecology

1996

\title{
Decreases in ovarian cytochrome P450c17 alpha activity and serum free testosterone after reduction of insulin secretion in polycystic ovary syndrome
}

John E. Nestler, M.D.

Virginia Commonwealth University, Medical College of Virginia, jnestler@mcvh-vcu.edu

Daniela J. Jakubowicz, M.D.

Hospital de Clinicas Caracas

Follow this and additional works at: http://scholarscompass.vcu.edu/obgyn_pubs

Part of the Obstetrics and Gynecology Commons

From The New England Journal of Medicine, Nestler, J. E. and Jakubowicz, D.J., Decreases in ovarian cytochrome P450c17 alpha activity and serum free testosterone after reduction of insulin secretion in polycystic ovary syndrome, Vol. 335, Page 617, Copyright (C) 1996 Massachusetts Medical Society. Reprinted with permission.

\section{Downloaded from}

http://scholarscompass.vcu.edu/obgyn_pubs/21

This Article is brought to you for free and open access by the Dept. of Obstetrics and Gynecology at VCU Scholars Compass. It has been accepted for inclusion in Obstetrics and Gynecology Publications by an authorized administrator of VCU Scholars Compass. For more information, please contact libcompass@vcu.edu. 


\title{
DECREASES IN OVARIAN CYTOCHROME P450c17 $\alpha$ ACTIVITY AND SERUM FREE TESTOSTERONE AFTER REDUCTION OF INSULIN SECRETION IN POLYCYSTIC OVARY SYNDROME
}

\author{
John E. Nestler, M.D., and Daniela J. Jakubowicz, M.D.
}

\begin{abstract}
Background Insulin resistance and increased ovarian cytochrome $\mathrm{P} 450 \mathrm{c} 17 \alpha$ activity are both features of the polycystic ovary syndrome. P450c17 $\alpha$, which is involved in androgen biosynthesis, has both $17 \alpha$-hydroxylase and 17,20-lyase activities. Increased activity of this enzyme results in exaggerated conversion of progesterone to $17 \alpha$-hydroxyprogesterone in response to stimulation by gonadotropin. We hypothesized that hyperinsulinemia stimulates ovarian $\mathrm{P} 450 \mathrm{c} 17 \alpha$ activity.

Methods We measured serum steroid concentrations during fasting and the response of serum $17 \alpha$-hydroxyprogesterone to leuprolide, a gonadotropin-releasing hormone agonist, and performed oral glucose-tolerance tests before and after oral administration of either metformin $(500 \mathrm{mg}$ three times daily) or placebo for four to eight weeks in 24 obese women with the polycystic ovary syndrome.

Results In the 11 women given metformin, the mean $( \pm S E)$ area under the serum insulin curve after oral glucose administration decreased from $9303 \pm 1603$ to $4982 \pm 911 \mu \mathrm{U}$ per milliliter per minute ( $56 \pm 10$ to $30 \pm 6 \mathrm{nmol}$ per liter per minute) $(P=0.004)$. This decrease was associated with a reduction in the basal serum $17 \alpha$-hydroxyprogesterone concentration from $135 \pm 21$ to $66 \pm 7 \mathrm{ng}$ per deciliter $(4.1 \pm 0.6$ to $2.0 \pm 0.2 \mathrm{nmol}$ per liter) $(\mathrm{P}=0.01)$ and a reduction in the leuprolide-stimulated peak serum $17 \alpha$-hydroxyprogesterone concentration from $455 \pm 54$ to $281 \pm 52 \mathrm{ng}$ per deciliter (13.7 \pm 1.6 to $8.5 \pm 1.6 \mathrm{nmol}$ per liter) $(P=0.01)$. The serum $17 \alpha$-hydroxyprogesterone values increased slightly in the placebo group. In the metformin group, the basal serum luteinizing hormone concentration decreased from $8.5 \pm 2.2$ to $2.8 \pm 0.5 \mathrm{mlU}$ per milliliter $(P=0.01)$, the serum free testosterone concentration decreased from $0.34 \pm 0.07$ to $0.19 \pm 0.05$ ng per deciliter (12 \pm 3 to $7 \pm 2$ pmol per liter) $(P=0.009)$, and the serum sex hormone-binding globulin concentration increased from $0.8 \pm 0.2$ to $2.3 \pm 0.6 \mu \mathrm{g}$ per deciliter $(29 \pm 7$ to $80 \pm 21 \mathrm{nmol}$ per liter) $(P<0.001)$. None of these values changed significantly in the placebo group.

Conclusions In obese women with the polycystic ovary syndrome, decreasing serum insulin concentrations with metformin reduces ovarian cytochrome P450c17 $\alpha$ activity and ameliorates hyperandrogenism. (N Engl J Med 1996;335:617-23.)

(C)1996, Massachusetts Medical Society.
\end{abstract}

$\mathrm{T}$ HE polycystic ovary syndrome is characterized by anovulation and hyperandrogenism. It affects approximately 6 percent of women of reproductive age. ${ }^{1}$ Insulin resistance accompanied by compensatory hyperinsulinemia is a common feature of the syndrome, and both obese and nonobese women with the syndrome are more insulin-resistant and hyperinsulinemic than age- and weight-matched normal women. ${ }^{2-9}$

Hyperinsulinemia may play a pathogenetic part in hyperandrogenism in women with the polycystic ovary syndrome by increasing ovarian androgen production and decreasing the serum sex hormonebinding globulin concentration. ${ }^{10-17}$ Serum free testosterone concentrations decline in women with the polycystic ovary syndrome when their insulin secretion is reduced by the administration of diazoxide ${ }^{15}$ or metformin ${ }^{18}$ or by diet. ${ }^{19,20}$ Furthermore, the observation that adolescent girls with hyperandrogenism have insulin resistance ${ }^{9}$ suggests that hyperinsulinemia may play an early and central part in the pathogenesis of the polycystic ovary syndrome.

Cytochrome $\mathrm{P} 450 \mathrm{cl} 7 \alpha$ is a bifunctional enzyme that has both $17 \alpha$-hydroxylase and 17,20-lyase activities, and it is a key enzyme in the biosynthesis of ovarian androgens. In ovarian theca cells, $\mathrm{P} 450 \mathrm{cl} 7 \alpha$ converts progesterone to $17 \alpha$-hydroxyprogesterone through its $17 \alpha$-hydroxylase activity, and then converts $17 \alpha$-hydroxyprogesterone to androstenedione through its 17,20-lyase activity. Androstenedione is then converted to testosterone by the enzyme $17 \beta$-reductase (Fig. 1).

Many women with the polycystic ovary syndrome have increased ovarian cytochrome $\mathrm{P} 450 \mathrm{cl} 7 \alpha$ activity,,$^{21,22}$ as evidenced by increased $17 \alpha$-hydroxylase and, to a lesser extent, 17,20-lyase activity, resulting in excessive ovarian androgen production. In these women, a hallmark of increased ovarian $\mathrm{P} 450 \mathrm{cl} 7 \alpha$ activity is an exaggerated serum $17 \alpha$-hydroxyprogesterone response to stimulation by gonadotropin-

From the Departments of Internal Medicine, Obstetrics and Gynecology, and Pharmacology and Toxicology, Division of Endocrinology and Metabolism, Medical College of Virginia, Virginia Commonwealth University, Richmond (J.E.N.); and the Department of Internal Medicine, Hospital de Clinicas Caracas, Caracas, Venezuela (D.J.J.). Address reprint requests to Dr. Nestler at the Medical College of Virginia, P.O. Box 980111, Richmond, VA 23298-0111 
releasing hormone agonists, such as nafarelin, ${ }^{21-23}$ buserelin, ${ }^{24}$ and leuprolide. ${ }^{25}$ Whether the increased ovarian $\mathrm{P} 450 \mathrm{c} 17 \alpha$ activity in women with the polycystic ovary syndrome is an inherited or an acquired phenomenon is not known.

We hypothesized that hyperinsulinemia stimulates ovarian cytochrome $\mathrm{P} 450 \mathrm{cl} 17 \alpha$ activity in women with the polycystic ovary syndrome (Fig. 1) and that amelioration of insulin resistance in these women would return the activity of the enzyme toward normal. To test this hypothesis, we measured the basal serum $17 \alpha$-hydroxyprogesterone concentration and the serum $17 \alpha$-hydroxyprogesterone response to the administration of leuprolide in obese women with the polycystic ovary syndrome before and after the administration of metformin, which inhibits the production of hepatic glucose and enhances the sensitivity of peripheral tissue to insulin, thereby decreasing insulin secretion. ${ }^{26,27}$

\section{METHODS}

\section{Subjects}

We enrolled 25 women who were 18 to 35 years old, 24 of whom completed the study. All the women had the polycystic ovary syndrome, as defined by oligomenorrhea (fewer than six menstrual periods in the previous year) and hyperandrogenemia (elevated serum free testosterone concentrations), and were obese (body-mass index [weight in kilograms divided by the square of the height in meters], $\geqslant 27.5$ ). All had hirsutism, and 15 had acanthosis nigricans. Two women had each delivered two children, five women had each delivered one child, and the rest were childless. All had normal serum prolactin concentrations and normal results on thyroid-function tests. Late-onset congenital adrenal hyperplasia was ruled out by a morning serum $17 \alpha$-hydroxyprogesterone concentration of less than $200 \mathrm{ng}$ per deciliter $(6 \mathrm{nmol}$ per liter). All the women had findings on ultrasonography of the ovaries that were consistent with the diagnosis of the polycystic ovary syndrome. ${ }^{28}$ None had taken any medications for at least two months, and none had diabetes mellitus. Twelve women were randomly assigned to receive metformin (Glafornil, North Medicamenta, Caracas, Venezuela) and 13 women to receive placebo. The study was approved by the institutional review board of the Hospital de Clinicas Caracas, and each woman gave informed consent.

\section{Study Protocol}

The women were evaluated during the follicular phase of the menstrual cycle, as determined by a serum progesterone concentration of less than $2 \mathrm{ng}$ per milliliter $(6.4 \mathrm{nmol}$ per liter). On day 1 the women came to the hospital after a 12 -hour overnight fast, and their weight, height, waist-to-hip ratio, and blood pressure while supine were measured. Blood samples were drawn at 8:30, $8: 45$, and 9 a.m., and equal volumes of serum were pooled for the measurement of insulin, glucose, steroids, and sex hormonebinding globulin. At 9 a.m., $75 \mathrm{~g}$ of dextrose (Glycolab, Relab Laboratory, Caracas, Venezuela) was given orally. Blood samples were collected for determinations of serum glucose and insulin concentrations at 60 and 120 minutes.

On day 2 the women ate breakfast at 9 a.m. and then fasted until 2 p.m., when a leuprolide stimulation test was performed.

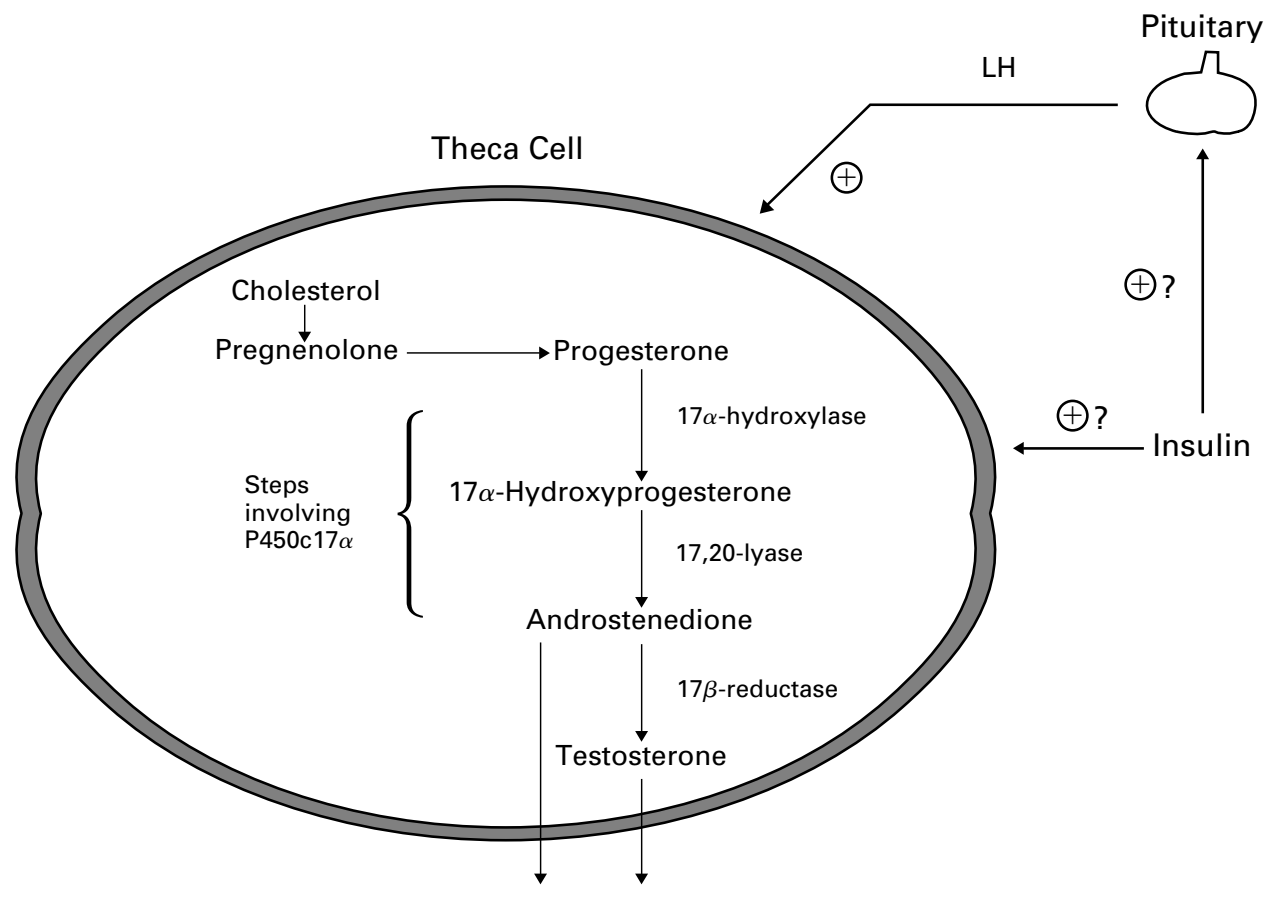

Figure 1. Possible Mechanisms of Insulin Stimulation of Ovarian Cytochrome P450c17 $\alpha$ Activity and Androgen Production. In theca cells, insulin may directly stimulate (plus signs) ovarian cytochrome P450c17 $\alpha$, resulting in increased $17 \alpha$ hydroxylase and, to a lesser extent, 17,20-lyase activity. This would lead to increased production of androstenedione, which is then converted to testosterone by the enzyme $17 \beta$-reductase. Alternatively or in conjunction with this, insulin may stimulate ovarian androgen production indirectly by enhancing the amplitude of serum luteinizing hormone (LH) pulses, and luteinizing hormone may then stimulate ovarian cytochrome P450c17 $\alpha$ activity. 
After this test the women took $500 \mathrm{mg}$ of metformin or placebo orally three times daily. They were instructed not to alter their usual eating habits, physical activity, or lifestyle during the study.

The women returned for studies four to eight weeks later, after a low serum progesterone value had confirmed that they were in the follicular phase of the menstrual cycle. Five women had serum progesterone values in the postovulatory range after taking metformin for four weeks. One of them became pregnant despite long-standing infertility; she was dropped from the study and her results were omitted from the analysis. The remaining four women continued to take metformin and were studied four weeks later when their serum progesterone values were low. In the placebo group, one woman had a serum progesterone value in the postovulatory range after four weeks; she was studied again two weeks later.

\section{Leuprolide Stimulation Test}

After base-line blood samples had been obtained at 2 p.m. on day 2 , leuprolide (10 $\mu \mathrm{g}$ per kilogram of body weight; Lupron, Abbott Laboratories, Takeda, Japan) was administered subcutaneously. Blood samples for the measurement of serum luteinizing hormone were collected immediately before and $0.5,1,16,20$, and 24 hours after leuprolide was administered. Blood samples for the measurement of serum $17 \alpha$-hydroxyprogesterone were collected immediately before and 16, 20, and 24 hours after leuprolide was administered. The women ate an evening meal on day 2 but fasted thereafter until the completion of the test. The early response of serum luteinizing hormone was determined from pooled equal volumes of serum taken at 0.5 and 1 hour, and the late serum luteinizing hormone response from pooled equal volumes of serum taken at 16,20, and 24 hours. The serum concentration of $17 \alpha$-hydroxyprogesterone measured immediately before the administration of leuprolide was considered the basal value, and the highest serum concentration of $17 \alpha$-hydroxyprogesterone that was measured after the administration of leuprolide was considered the peak value.

\section{Assays}

The blood samples were centrifuged immediately, and the serum was stored at $-20^{\circ} \mathrm{C}$ until it was assayed. The serum free testosterone concentration was determined by radioimmunoassay (Diagnostic Products, Los Angeles). All other hormones and sex hormone-binding globulin (measured as protein) were assayed as previously described. ${ }^{15,17,29}$ To avoid variation among assays, all samples were analyzed in duplicate in a single assay for each hormone. The intraassay coefficients of variation for the insulin and luteinizing hormone assays were 5.5 and 1.6 percent, respectively, and they were less than 10 percent for all the steroid hormone assays.

\section{Statistical Analysis}

The results are reported as means \pm SE. Within a group, we compared the results before treatment with those after treatment by testing for normality with the Wilk-Shapiro test and using Student's two-tailed paired t-test or the Wilcoxon signed-rank test. Comparisons between groups were made with Student's twotailed unpaired t-test or the Mann-Whitney rank-sum test.

We analyzed the responses of serum glucose and insulin to the oral administration of glucose and the responses of serum luteinizing hormone and $17 \alpha$-hydroxyprogesterone to the administration of leuprolide by calculating the areas under the response curves by the trapezoidal rule using absolute values.

\section{RESULTS}

\section{Base-Line Characteristics}

The women in the metformin and placebo groups did not differ significantly in age, body-mass index, waist-to-hip ratio, blood pressure, or serum concen- trations of sex steroids or sex hormone-binding globulin at base line (Table 1). They also did not differ at base line in serum insulin or glucose values measured during fasting, insulin or glucose responses after oral glucose administration, or basal or leuprolide-stimulated serum $17 \alpha$-hydroxyprogesterone values (Table 1 and Fig. 2). The base-line serum luteinizing hormone concentration was higher in the metformin group than in the placebo group $(8.5 \pm 2.2$ vs. $3.7 \pm 0.7$ mIU per milliliter; $\mathrm{P}=0.04$ ) (Fig. 3).

\section{Anthropometric Variables}

The body-mass index did not change significantly during the study in either group. The waist-to-hip ratio decreased slightly in the metformin group $(P=0.02)$ but did not change substantially in the placebo group. There was no significant change in diastolic or systolic blood pressure in either group.

\section{Serum Insulin and Glucose Profiles}

In the metformin group, the mean serum insulin concentration measured during fasting decreased from $17 \pm 3$ to $9 \pm 2 \mu \mathrm{U}$ per milliliter (102 \pm 18 to $54 \pm 12$ pmol per liter $)(\mathrm{P}=0.03)$, and the area under the serum insulin curve decreased from 9303 \pm 1603 to $4982 \pm 911 \mu \mathrm{U}$ per milliliter per minute $(56 \pm 10$ to $30 \pm 6 \mathrm{nmol}$ per liter per minute) $(\mathrm{P}=0.004)(\mathrm{Ta}-$ ble 1). Neither of these values changed significantly in the placebo group. The serum glucose concentration in fasting women did not change significantly in either group. The area under the serum glucose curve increased in the placebo group $(\mathrm{P}=0.03)$ but did not change substantially in the metformin group.

\section{Responses of Serum Luteinizing Hormone to Leuprolide}

The basal serum luteinizing hormone concentration decreased from $8.5 \pm 2.2$ to $2.8 \pm 0.5 \mathrm{mIU}$ per milliliter $(\mathrm{P}=0.01)$ in the metformin group but did not change significantly in the placebo group (Fig. 3 ). The early serum luteinizing hormone responses to leuprolide were lower after the administration of metformin than at base line $(17.0 \pm 2.5$ vs. $40.8 \pm 11.9$ mIU per milliliter, $\mathrm{P}=0.01)$. The late serum luteinizing hormone responses were slightly but not significantly lower after the administration of metfor$\min (\mathrm{P}=0.26)$. In contrast, in the placebo group the basal serum luteinizing hormone concentrations and the early and late serum luteinizing hormone responses to leuprolide were virtually identical at base line and after the administration of placebo (Fig. 3).

\section{Serum $17 \alpha$-Hydroxyprogesterone Responses}

In the metformin group, the mean basal serum $17 \alpha$-hydroxyprogesterone concentration decreased by 51 percent, from $135 \pm 21$ to $66 \pm 7 \mathrm{ng}$ per deciliter $(4.1 \pm 0.6$ to $2.0 \pm 0.2 \mathrm{nmol}$ per liter $)(\mathrm{P}=0.01)$, but it did not change significantly in the placebo 
Table 1. Characteristics of Women with the Polycystic Ovary Syndrome at Base Line and after the Administration of Metformin or Placebo for Four to Eight Weeks.*

\begin{tabular}{|c|c|c|c|c|}
\hline \multirow[t]{2}{*}{ Characteristic } & \multicolumn{2}{|c|}{ Metformin Group $(\mathbf{N}=\mathbf{1 1})$} & \multicolumn{2}{|c|}{ Placebo Group ( $N=13$ ) } \\
\hline & BASE LINE & AFTER METFORMIN & BASE LINE & AFTER PLACEBO \\
\hline Age $(\mathrm{yr})$ & $29 \pm 1$ & - & $29 \pm 2$ & - \\
\hline Body-mass index & $34.1 \pm 1.5$ & $34.1 \pm 1.3$ & $35.2 \pm 1.9$ & $35.2 \pm 1.9$ \\
\hline Waist-to-hip ratio & $0.86 \pm 0.01$ & $0.85 \pm 0.02 \dagger$ & $0.86 \pm 0.01$ & $0.87 \pm 0.01$ \\
\hline $\begin{array}{l}\text { Blood pressure }(\mathrm{mm} \mathrm{Hg}) \\
\text { Systolic } \\
\text { Diastolic }\end{array}$ & $\begin{array}{r}128 \pm 2 \\
87 \pm 1\end{array}$ & $\begin{array}{r}127 \pm 2 \\
83 \pm 1\end{array}$ & $\begin{array}{r}132 \pm 4 \\
88 \pm 2\end{array}$ & $\begin{array}{r}134 \pm 3 \\
88 \pm 2\end{array}$ \\
\hline Fasting serum insulin $(\mu \mathrm{U} / \mathrm{ml})$ & $17 \pm 3$ & $9 \pm 2 \ddagger$ & $28 \pm 5$ & $31 \pm 5$ \\
\hline AUC for insulin $(\mu \mathrm{U} / \mathrm{ml} / \mathrm{min}) \mathfrak{S}$ & $9,303 \pm 1603$ & $4,982 \pm 911 \mathbb{I}$ & $9,022 \pm 1046$ & $9,970 \pm 1119$ \\
\hline Fasting serum glucose $(\mathrm{mg} / \mathrm{dl})$ & $79 \pm 2$ & $76 \pm 2$ & $83 \pm 4$ & $86 \pm 3$ \\
\hline AUC for glucose $(\mathrm{mg} / \mathrm{dl} / \mathrm{min}) \mathbb{S}$ & $11,382 \pm 406$ & $11,189 \pm 679$ & $12,224 \pm 524$ & $13,448 \pm 526 \ddagger$ \\
\hline Serum progesterone $(\mathrm{ng} / \mathrm{ml})$ & $0.8 \pm 0.1$ & $0.8 \pm 0.1$ & $1.0 \pm 0.2$ & $0.8 \pm 0.1$ \\
\hline Serum testosterone $(\mathrm{ng} / \mathrm{dl})$ & $90 \pm 17$ & $68 \pm 14$ & $69 \pm 14$ & $81 \pm 11$ \\
\hline Serum free testosterone $(\mathrm{ng} / \mathrm{dl})$ & $0.34 \pm 0.07$ & $0.19 \pm 0.05 \|$ & $0.21 \pm 0.05$ & $0.27 \pm 0.06$ \\
\hline Serum androstenedione $(\mathrm{ng} / \mathrm{dl})$ & $324 \pm 29$ & $289 \pm 25$ & $259 \pm 20$ & $272 \pm 18$ \\
\hline Serum $17 \beta$-estradiol $(\mathrm{ng} / \mathrm{dl})$ & $10.6 \pm 1.3$ & $9.0 \pm 1.1$ & $8.0 \pm 0.9$ & $8.9 \pm 0.7$ \\
\hline Serum dehydroepiandrosterone sulfate $(\mu \mathrm{g} / \mathrm{dl})$ & $176 \pm 22$ & $196 \pm 21$ & $170 \pm 19$ & $180 \pm 18$ \\
\hline Serum sex hormone-binding globulin $(\mu \mathrm{g} / \mathrm{dl})$ & $0.8 \pm 0.2$ & $2.3 \pm 0.6^{* *}$ & $0.8 \pm 0.1$ & $0.9 \pm 0.1$ \\
\hline
\end{tabular}

*The mean $( \pm S E)$ length of administration was $42 \pm 4$ days in the metformin group and $32 \pm 2$ days in the placebo group. Plus-minus values are means \pm SE. To convert values for insulin to picomoles per liter, multiply by 6.0 ; to convert values for glucose to millimoles per liter, multiply by 0.056 ; to convert values for progesterone to nanomoles per liter, multiply by 3.2 ; to convert values for testosterone to picomoles per liter, multiply by 34.7 ; to convert values for androstenedione to picomoles per liter, multiply by 34.9 ; to convert values for $17 \beta$-estradiol to picomoles per liter, multiply by 36.7 ; to convert values for dehydroepiandrosterone sulfate to micromoles per liter, multiply by 0.027 ; and to convert values for sex hormone-binding globulin to nanomoles per liter, multiply by 34.7. The normal ranges for ovulatory women are as follows: insulin, 5 to $20 \mu \mathrm{U}$ per milliliter; progesterone, $<2.0 \mathrm{ng}$ per milliliter during the follicular phase; testosterone, 22 to $70 \mathrm{ng}$ per deciliter; free testosterone, 0.06 to $0.19 \mathrm{ng}$ per deciliter; androstenedione, 66 to $300 \mathrm{ng}$ per deciliter; $17 \beta$-estradiol, 1 to $20 \mathrm{ng}$ per deciliter (early follicular to midfollicular phase); dehydroepiandrosterone sulfate,

35 to $430 \mu \mathrm{g}$ per deciliter; and sex hormone-binding globulin, 0.6 to $4.0 \mu \mathrm{g}$ per deciliter.

$\dagger \mathrm{P}=0.02$ for the comparison with base line.

$\ddagger \mathrm{P}=0.03$ for the comparison with base line.

SValues are for the area under the curve (AUC) during an oral glucose-tolerance test.

$\Phi \mathrm{P}=0.004$ for the comparison with base line.

$\| \mathrm{P}=0.009$ for the comparison with base line.

${ }^{*} \mathrm{P}<0.001$ for the comparison with base line.

group (Fig. 2). Similarly, in the metformin group the peak serum $17 \alpha$-hydroxyprogesterone concentration after leuprolide administration decreased from $455 \pm 54$ to $281 \pm 52 \mathrm{ng}$ per deciliter ( $13.7 \pm 1.6$ to $8.5 \pm 1.6 \mathrm{nmol}$ per liter $)(\mathrm{P}=0.01)$, and the area under the serum $17 \alpha$-hydroxyprogesterone curve decreased from $7848 \pm 945$ to $4592 \pm 766$ ng per deciliter per hour $(237 \pm 29$ to $139 \pm 23 \mathrm{nmol}$ per liter per hour $)(\mathrm{P}=0.004)$, whereas these values increased slightly in the placebo group (Fig. 2). The change in the area under the serum $17 \alpha$-hydroxyprogesterone curve in the metformin group differed significantly from that in the placebo group $(-3256 \pm 180$ vs. $912 \pm 105 \mathrm{ng}$ per deciliter per hour $[-98 \pm 27$ vs. $28 \pm 10 \mathrm{nmol}$ per liter per hour] $)(\mathrm{P}<0.001)$, and the area under the serum $17 \alpha$-hydroxyprogesterone curve was significantly less after metformin administration than after placebo administration ( $4592 \pm 766$ vs. $6949 \pm 685 \mathrm{ng}$ per deciliter per hour
[139 \pm 21 vs. $210 \pm 21 \mathrm{nmol}$ per liter per hour]) $(\mathrm{P}=0.02)$.

\section{Serum Sex Steroids}

The administration of metformin was associated with a 44 percent decrease in serum free testosterone concentrations, from $0.34 \pm 0.07$ to $0.19 \pm 0.05 \mathrm{ng}$ per deciliter ( $12 \pm 2$ to $7 \pm 2$ pmol per liter $)(\mathrm{P}=0.009)$, and a threefold increase in serum sex hormone-binding globulin concentrations, from $0.8 \pm 0.2$ to $2.3 \pm 0.6$ $\mu \mathrm{g}$ per deciliter $(29 \pm 7$ to $80 \pm 21 \mathrm{nmol}$ per liter) $(\mathrm{P}<0.001)$ (Table 1$)$. These values did not change significantly in the placebo group. The serum concentrations of the other measured steroids did not change substantially in either group.

\section{DISCUSSION}

In these women with the polycystic ovary syndrome, the administration of metformin reduced the 

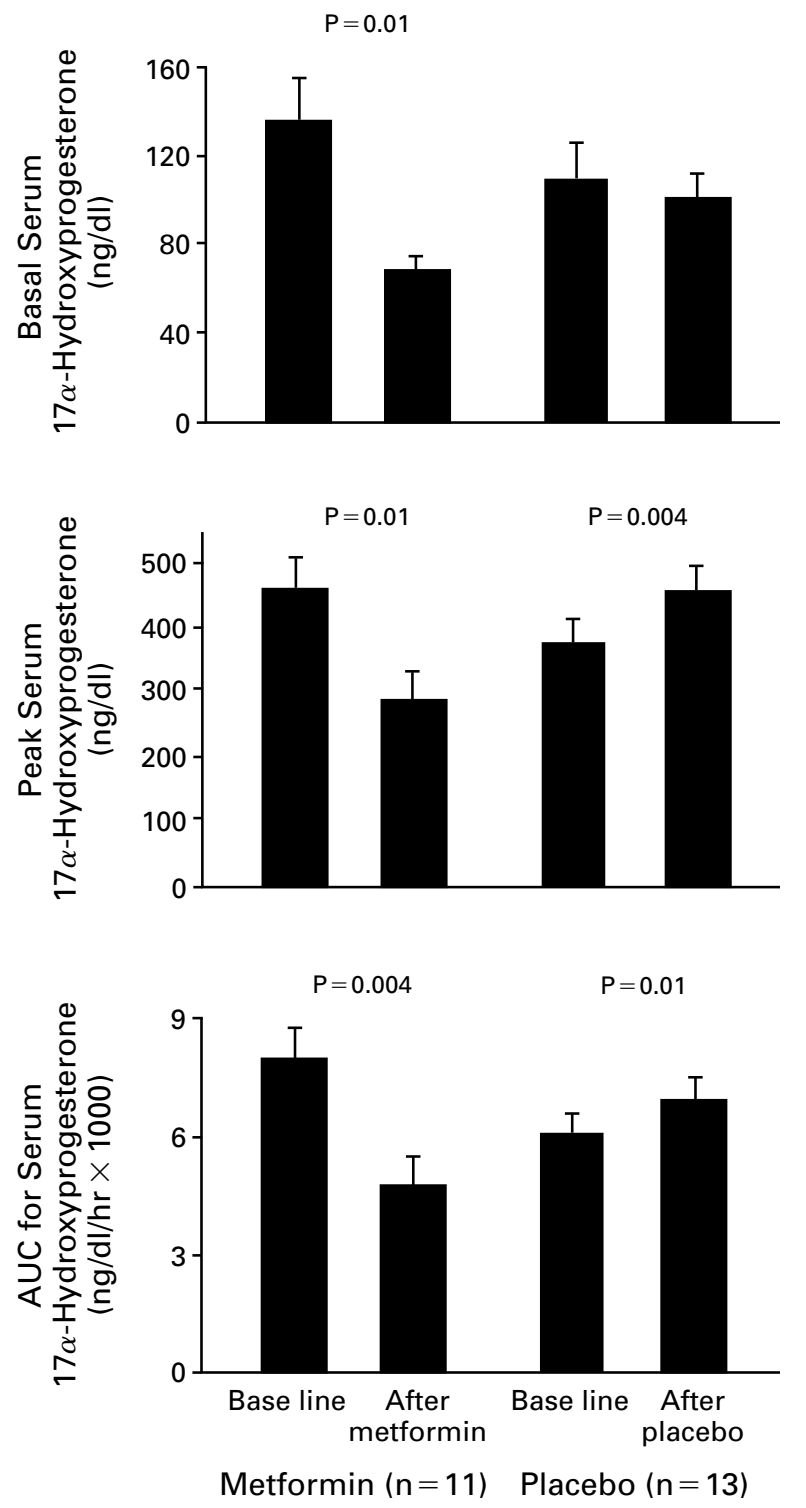

Figure 2. Mean $( \pm \mathrm{SE})$ Serum $17 \alpha$-Hydroxyprogesterone Concentrations in Women with the Polycystic Ovary Syndrome at Base Line and after the Administration of Metformin or Placebo for Four to Eight Weeks.

Metformin was administered for a mean ( $\pm S E$ ) of $42 \pm 4$ days, and placebo for $32 \pm 2$ days. The women were studied before and after the administration of leuprolide ( $10 \mu \mathrm{g}$ per kilogram). To convert values for $17 \alpha$-hydroxyprogesterone to nanomoles per liter, multiply by 0.03 . AUC denotes area under the curve.

serum insulin concentration during fasting and the insulin response to oral glucose administration. Concomitantly, ovarian cytochrome $\mathrm{P} 450 \mathrm{cl} 7 \alpha$ activity decreased, as demonstrated by a substantial reduction in the response of serum $17 \alpha$-hydroxyprogesterone to the administration of leuprolide (to increase luteinizing hormone secretion). The reduction in P450cl7 $\alpha$ activity was accompanied by a decline in

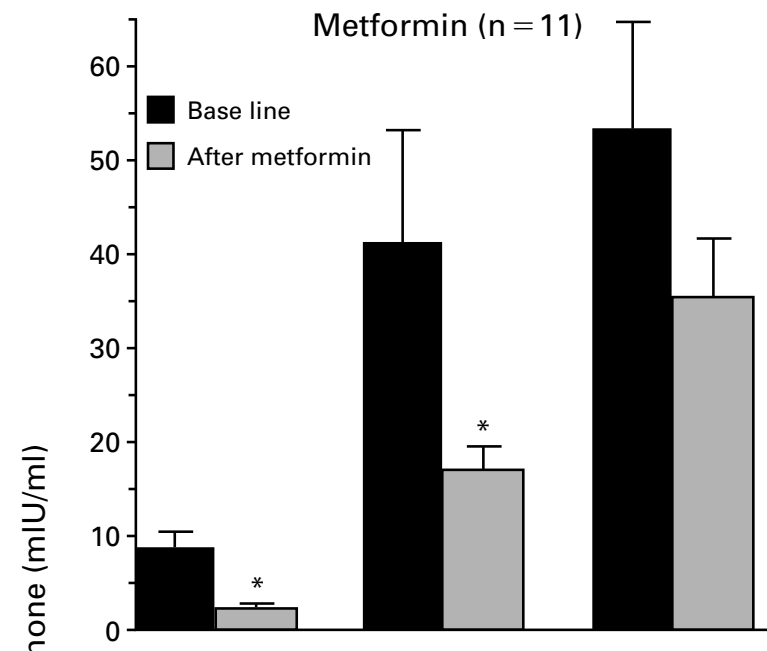

Placebo $(n=13)$

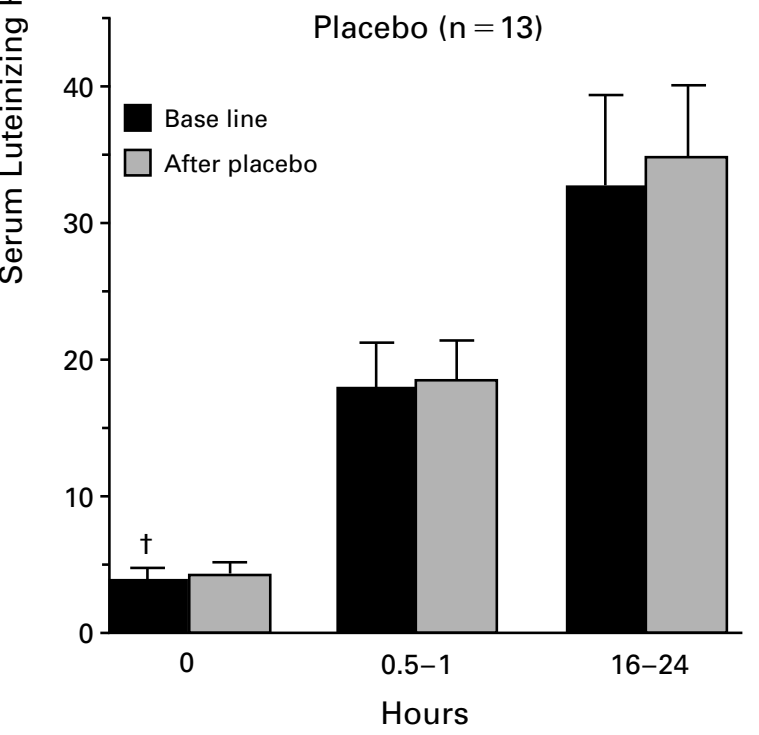

Figure 3. Mean $( \pm S E)$ Serum Luteinizing Hormone Concentrations in Women with the Polycystic Ovary Syndrome at Base Line and after the Administration of Metformin or Placebo for Four to Eight Weeks.

Metformin was administered for a mean ( \pm SE) of $42 \pm 4$ days, and placebo for $32 \pm 2$ days. The women were studied before and after administration of leuprolide (10 $\mu \mathrm{g}$ per kilogram). The asterisks indicate $\mathrm{P}=0.01$ for the comparison with the base-line value in same group, and the dagger indicates $\mathrm{P}=0.04$ for the comparison with the base-line value in the metformin group.

the serum free testosterone concentration. These findings suggest that increased ovarian cytochrome P450c17 $\alpha$ activity in women with the polycystic ovary syndrome is due to stimulation by insulin (Fig. 1) and can be reversed by reducing the secretion of insulin. We intentionally did not screen the women for the presence of insulin resistance or increased $\mathrm{P} 450 \mathrm{cl} 7 \alpha$ activity so that our results would be ap- 
plicable to unselected women with the polycystic ovary syndrome.

We cannot exclude the possibility that the decrease in ovarian $\mathrm{P} 450 \mathrm{cl} 1 \alpha$ activity resulted from the reduction in serum free testosterone or a direct action of metformin, but these possibilities seem remote. Hyperandrogenism is a consequence of increased ovarian $\mathrm{P} 450 \mathrm{cl} 7 \alpha$ activity and is therefore unlikely to be the cause of the stimulated enzyme activity. Hyperandrogenism in women with the polycystic ovary syndrome is ameliorated by diazoxide ${ }^{15}-\mathrm{a}$ drug structurally unrelated to metformin that suppresses insulin release and worsens glucose tolerance - and by diet. ${ }^{19,20}$ The common factor among these diverse therapies appears to be the reduction in serum insulin concentrations. Because diazoxide is not known to alter insulin sensitivity yet lowers serum testosterone concentrations in women with the polycystic ovary syndrome, ${ }^{15}$ hyperandrogenism in such women appears to be related to hyperinsulinemia itself and not to insulin resistance; moreover, insulin stimulates ovarian androgen production in vitro. ${ }^{11-14}$ The recent report by Moghetti et al. ${ }^{30}$ that hyperinsulinemia may stimulate cytochrome $\mathrm{P} 450 \mathrm{cl} 7 \alpha$ activity in another steroidogenic tissue of women with the polycystic ovary syndrome - namely, the adrenal glands - further supports our findings.

The early and late serum luteinizing hormone responses to leuprolide after the administration of placebo were almost identical to those at base line. In contrast, the administration of metformin was associated with decreased basal and leuprolide-stimulated serum luteinizing hormone concentrations. These observations raise the possibility that insulin enhances both the endogenous (basal) and the exogenous (leuprolide-stimulated) release of luteinizing hormone mediated by gonadotropin-releasing hormone and that increased ovarian cytochrome $\mathrm{P} 450 \mathrm{cl} 7 \alpha$ activity in women with the polycystic ovary syndrome may be related to an insulin-induced abnormality in the dynamics of gonadotropin secretion rather than (wholly or partially) to direct stimulation of ovarian steroidogenesis by insulin (Fig. 1). Insulin receptors have been identified in human pituitary tissue, ${ }^{31}$ and insulin augments the release of luteinizing hormone by cultured rat pituitary cells. ${ }^{32}$

The secretion of luteinizing hormone is often increased in women with the polycystic ovary syndrome, ${ }^{33}$ and the diurnal changes in the serum concentrations of luteinizing hormone and insulin in these women follow a similar time course. ${ }^{34}$ Preliminary studies suggest that insulin enhances the amplitude of serum luteinizing hormone pulses but not their frequency in obese women with the polycystic ovary syndrome (unpublished data). An alternative possibility is that the reduction in luteinizing hormone secretion in the women we studied was due to a decrease in the concentration of circulating androgens. However, raising serum androgen concentrations by parenteral administration in normal women ${ }^{35}$ or women with the polycystic ovary syndrome ${ }^{36}$ does not stimulate the secretion of luteinizing hormone. Finally, some of the women in our study who received metformin ovulated, and ovulation itself may influence the dynamics of gonadotropin secretion. ${ }^{37}$ However, in our study the results in the women who had ovulated and those who had not were similar.

The metformin-induced reduction in insulin secretion was associated with substantial decreases in serum free testosterone concentrations and increases in serum sex hormone-binding globulin concentrations. In women with the polycystic ovary syndrome, insulin stimulates ovarian androgen production ${ }^{11-15}$ and lowers serum sex hormone-binding globulin concentrations. ${ }^{16,17}$ Our findings, and those of an uncontrolled trial ${ }^{18}$ of metformin in women with the polycystic ovary syndrome, support these observations. In contrast, Crave et al. found that neither serum testosterone nor sex hormone-binding globulin concentrations changed in women with the polycystic ovary syndrome who were treated with a hypocaloric diet and metformin for four months. ${ }^{38}$ The reasons for the discrepancies among these studies are unknown.

In summary, our findings suggest that two features of the polycystic ovary syndrome - hyperinsulinemic insulin resistance and increased ovarian cytochrome $\mathrm{P} 450 \mathrm{cl} 7 \alpha$ activity - are pathogenetically linked, and that hyperinsulinemia stimulates this enzyme either directly or indirectly by increasing gonadotropin secretion (Fig. 1). The ability of insulin to stimulate ovarian cytochrome $\mathrm{P} 450 \mathrm{c} 17 \alpha$ is probably limited to women with the polycystic ovary syndrome and may be a heritable abnormality, since many other obese women who also are hyperinsulinemic have neither hyperandrogenism nor hyperresponsiveness to gonadotropin-releasing hormone. ${ }^{22}$ The clinical implication of these results is that therapeutic measures directed at lowering insulin secretion in women with the polycystic ovary syndrome should ameliorate their hyperandrogenism.

Supported in part by grants (ROlAG11227 and ROlCA64500) from the National Institutes of Health (to Dr. Nestler).

We are indebted to Ms. Terre Williams, Ms. Carmen Medina, and Ms. Gladys Coz for technical assistance.

\section{REFERENCES}

1. Franks S. Polycystic ovary syndrome. N Engl J Med 1995;333:853-61. [Erratum, N Engl J Med 1995;333:1435.]

2. Chang RJ, Nakamura RM, Judd HL, Kaplan SA. Insulin resistance in nonobese patients with polycystic ovarian disease. J Clin Endocrinol Metab 1983;57:356-9.

3. Dunaif A, Segal KR, Futterweit W, Dobrjansky A. Profound peripheral insulin resistance, independent of obesity, in polycystic ovary syndrome. Diabetes 1989;38:1165-74.

4. Dunaif A, Green G, Futterweit W, Dobrjansky A. Suppression of hyper- 
androgenism does not improve peripheral or hepatic insulin resistance in the polycystic ovary syndrome. J Clin Endocrinol Metab 1990;70:699704.

5. Carmina E, Koyama T, Chang L, Stanczyk FZ, Lobo RA. Does ethnicity influence the prevalence of adrenal hyperandrogenism and insulin resist ance in polycystic ovary syndrome? Am J Obstet Gynecol 1992;167:1807 12 .

6. Ciaraldi TP, el-Roeiy A, Madar Z, Reichart D, Olefsky JM, Yen SSC. Cellular mechanisms of insulin resistance in polycystic ovarian syndrome. J Clin Endocrinol Metab 1992;75:577-83.

7. Dunaif A, Xia J, Book CB, Schenker E, Tang Z. Excessive insulin receptor serine phosphorylation in cultured fibroblasts and in skeletal muscle: a potential mechanism for insulin resistance in the polycystic ovary syndrome. J Clin Invest 1995;96:801-10.

8. Ehrmann DA, Sturis J, Byrne MM, Karrison T, Rosenfield RL, Polonsky KS. Insulin secretory defects in polycystic ovary syndrome: relationship to insulin sensitivity and family history of non-insulin-dependent diabetes mellitus. J Clin Invest 1995;96:520-7.

9. Apter D, Butzow T, Laughlin GA, Yen SS. Metabolic features of poly cystic ovary syndrome are found in adolescent girls with hyperandrogenism. J Clin Endocrinol Metab 1995;80:2966-73.

10. Nestler JE. Role of obesity and insulin in the development of anovulation. In: Filicori M, Flamigni C, eds. Ovulation induction: basic science and clinical advances. Amsterdam: Elsevier Science B.V., 1994:103-14.

11. Barbieri RL, Makris A, Randall RW, Daniels G, Kistner RW, Ryan KJ. Insulin stimulates androgen accumulation in incubations of ovarian stroma obtained from women with hyperandrogenism. J Clin Endocrinol Metab 1986;62:904-10

12. Cara JF, Rosenfield RL. Insulin-like growth factor I and insulin poten tiate luteinizing hormone-induced androgen synthesis by rat ovarian the cal-interstitial cells. Endocrinology 1988;123:733-9.

13. Bergh C, Carlsson B, Olsson JH, Selleskog U, Hillensjo T. Regulation of androgen production in cultured human thecal cells by insulin-like growth factor I and insulin. Fertil Steril 1993;59:323-31.

14. Nahum R, Thong KJ, Hillier SG. Metabolic regulation of androgen production by human thecal cells in vitro. Hum Reprod 1995;10:75-81.

15. Nestler JE, Barlascini CO, Matt DW, et al. Suppression of serum insulin by diazoxide reduces serum testosterone levels in obese women with polycystic ovary syndrome. J Clin Endocrinol Metab 1989;68:1027-32.

16. Plymate SR, Matej LA, Jones RE, Friedl KE. Inhibition of sex hormone-binding globulin production in the human hepatoma (Hep G2) cell line by insulin and prolactin. J Clin Endocrinol Metab 1988;67:460-4.

17. Nestler JE, Powers LP, Matt DW, et al. A direct effect of hyperinsulinemia on serum sex hormone-binding globulin levels in obese women with the polycystic ovary syndrome. J Clin Endocrinol Metab 1991;72:83

18. Velazquez EM, Mendoza S, Hamer T, Sosa F, Glueck CJ. Metformin therapy in polycystic ovary syndrome reduces hyperinsulinemia, insulin re sistance, hyperandrogenemia, and systolic blood pressure, while facilitating normal menses and pregnancy. Metabolism 1994;43:647-54.

19. Kiddy DS, Hamilton-Fairley D, Seppälä M, et al. Diet-induced chang es in sex hormone binding globulin and free testosterone in women with normal or polycystic ovaries: correlation with serum insulin and insulin-like growth factor-I. Clin Endocrinol (Oxf) 1989;31:757-63.

20. Kiddy DS, Hamilton-Fairley D, Bush A, et al. Improvement in endocrine and ovarian function during dietary treatment of obese women with polycystic ovary syndrome. Clin Endocrinol (Oxf) 1992;36:105-11.

21. Ehrmann DA, Rosenfield RL, Barnes RB, Brigell DF, Sheikh Z. De- tection of functional ovarian hyperandrogenism in women with androgen excess. N Engl J Med 1992;327:157-62.

22. Rosenfield RL, Barnes RB, Ehrmann DA. Studies of the nature of 17-hydroxyprogesterone hyperresponsiveness to gonadotropin-releasing hormone agonist challenge in functional ovarian hyperandrogenism. J Clin Endocrinol Metab 1994;79:1686-92.

23. Luppa P, Muller B, Jacob K, et al. Variations of steroid hormone metabolites in serum and urine in polycystic ovary syndrome after nafarelin stimulation: evidence for an altered corticoid excretion. J Clin Endocrinol Metab 1995;80:280-8.

24. White D, Leigh A, Wilson C, Donaldson A, Franks S. Gonadotrophin and gonadal steroid response to a single dose of a long-acting agonist of gonadotrophin-releasing hormone in ovulatory and anovulatory women with polycystic ovary syndrome. Clin Endocrinol (Oxf) 1995:42:475-81. 25. Ibañez L, Potau N, Zampolli M, et al. Source localization of androgen excess in adolescent girls. J Clin Endocrinol Metab 1994;79:1778-84 26. Nagi DK, Yudkin JS. Effects of metformin on insulin resistance, risk factors for cardiovascular disease, and plasminogen activator inhibitor in NIDDM subjects: a study of two ethnic groups. Diabetes Care 1993;16: 621-9.

27. DeFronzo RA, Barzilai N, Simonson DC. Mechanism of metformin action in obese and lean noninsulin-dependent diabetic subjects. J Clin Endocrinol Metab 1991;73:1294-301

28. Yeh HC, Futterweit W, Thornton JC. Polycystic ovarian disease: US features in 104 patients. Radiology 1987;163:111-6.

29. Nestler JE, Beer NA, Jakubowicz DJ, Beer RM. Effects of a reduction in circulating insulin by metformin on serum dehydroepiandrosterone sulfate in nondiabetic men. J Clin Endocrinol Metab 1994;78:549-54.

30. Moghetti P, Castello R, Negri C, et al. Insulin infusion amplifies $17 \alpha$-hydroxycorticosteroid intermediates response to adrenocorticotropin in hyperandrogenic women: apparent relative impairment of 17,20-lyase ac tivity. J Clin Endocrinol Metab 1996;81:881-6.

31. Unger JW, Livingston JN, Moss AM. Insulin receptors in the central nervous system: localization, signalling mechanisms and functional aspects. Prog Neurobiol 1991;36:343-62.

32. Adashi EY, Hsueh AJW, Yen SSC. Insulin enhancement of luteinizing hormone and follicle-stimulating hormone release by cultured pituitary cells. Endocrinology 1981;108:1441-9.

33. Berga SL, Guzick DS, Winters SJ. Increased luteinizing hormone and $\alpha$-subunit secretion in women with hyperandrogenic anovulation. J Clin Endocrinol Metab 1993;77:895-901.

34. Yen SS, Laughlin GA, Morales AJ. Interface between extra- and intraovarian factors in polycystic ovarian syndrome. Ann N Y Acad Sci 1993;687: 98-111.

35. Spinder T, Spijkstra JJ, van den Tweel JG, et al. The effects of long term testosterone administration on pulsatile luteinizing hormone secretion and on ovarian histology in eugonadal female to male transsexual subjects. J Clin Endocrinol Metab 1989;69:151-7.

36. Dunaif A. Do androgens directly regulate gonadotropin secretion in the polycystic ovary syndrome? J Clin Endocrinol Metab 1986;63:215-21. 37. Blankstein J, Rabinovici J, Goldenberg M, et al. Changing pituitary reactivity to follicle-stimulating hormone and luteinizing hormone-releasing hormone after induced ovulatory cycles and after anovulation in patients with polycystic ovarian disease. J Clin Endocrinol Metab 1987;65:1164-7. 38. Crave JC, Fimbel S, Lejeune H, Cugnardey N, Déchaud H, Pugeat $\mathrm{M}$. Effects of diet and metformin administration on sex hormone-binding globulin, androgens, and insulin in hirsute and obese women. J Clin Endocrinol Metab 1995;80:2057-62. 